\title{
Resistance Enhancement of Transgenic Tomato to Bacterial Pathogens by the Heterologous Expression of Sweet Pepper Ferredoxin-I Protein
}

\author{
Hsiang-En Huang, Chien-An Liu, Mei-Jiuan Lee, C.-George Kuo, Huei-Mei Chen, Mang-Jye Ger, \\ Yu-Chih Tsai, Yen-Ru Chen, Ming-Kun Lin, and Teng-Yung Feng
}

First, seventh, eighth, ninth, and tenth authors: Academia Sinica-Plant and Microbial Biology, Institute of Plant and Microbial Biology, Academia Sinica, Nankang, Taipei 115, Taiwan; second, fourth, and fifth authors: Biotechnology and Plant Physiology, Asian Vegetable Research and Development Center, P.O. Box 42, Shanhua, Tainan, 741 Taiwan - Republic of China; third author: Taiwan Seed Improvement and Propagation Station, Taichung, 426, Taiwan, and Department of Horticultural Sciences, National Taiwan University, Taipei, 106, Taiwan; and sixth author: Department of Life Science, National University of Kaohsiung, Kaohsiung, 811, Taiwan. Accepted for publication 7 February 2007.

\begin{abstract}
Huang, H.-E., Liu, C.-A., Lee, M.-J., Kuo, C.-G., Chen, H.-M., Ger, M.-J., Tsai, Y.-C., Chen, Y.-R., Lin, M.-K., and Feng, T.-Y. 2007. Resistance enhancement of transgenic tomato to bacterial pathogens by the heterologous expression of sweet pepper ferredoxin-I protein. Phytopathology 97:900-906.

Expression of a foreign gene to enhance plant disease resistance to bacterial pathogens is a favorable strategy. It has been demonstrated that expressing sweet pepper ferredoxin-I protein (PFLP) in transgenic plants can enhance disease resistance to bacterial pathogens that infect leaf tissue. In this study, PFLP was applied to protect tomato (Lycopersicon esculentum cv. cherry Cln1558a) from the root-infecting pathogen, Ralstonia solanacearum. Independent $R$. solanacearum resistant $T_{1}$ lines

$\mathrm{T}_{2}$ transgenic lines 24-18-7 and 26-2-1a, which showed high expression levels of PFLP in root tissue, were resistant to disease caused by $R$. solanacearum. In contrast, the transgenic line $23-17-1 \mathrm{~b}$ and nontransgenic tomato, which showed low expression levels of PFLP in root tissue, were not resistant to $R$. solanacearum infection. The expansion of $R$. solanacearum populations in stem tissue of transgenic tomato line 24-18-7 was limited compared with the nontransgenic tomato Cln1558a. Using a detached leaf assay, transgenic line 24-18-7 was also resistant to maceration caused by E. carotovora subsp. carotovora; however, resistance to E. carotovora subsp. carotovora was less apparent in transgenic lines 262-1a and 23-17-1b. These results demonstrate that PFLP is able to enhance disease resistance at different levels to bacterial pathogens in individual tissue of transgenic tomato.
\end{abstract} were selected and bred to produce homozygous $\mathrm{T}_{2}$ generations. Selected
Reinforcement of resistance against pathogen attack using genetic engineering has proven to be an effective strategy to develop disease resistant crops $(13,14,29,30,32)$. Recently, it has been demonstrated that bacterial wilt caused by Ralstonia solanacearum, a devastating disease of tomato worldwide, can be alleviated by foreign proteins such as anti-microbial protein thionins (3), tomato stress-responsive factor TSRF1 (35), and transcription factor binding protein NPR1 $(4,7,22)$. Soft-rot disease caused by Erwinia carotovora subsp. carotovora could be alleviated by expression of foreign proteins such as 5-O-glucosyltransferase (23), hypersensitive response-assisting protein $(11,28)$, natural cecropin B analog shiva-1 peptide (34), novel cationic peptide MsrA3 (27), defense-related cationic peroxidase SPI2 (6), N-3-oxohexanoyl-1homoserine lactone producer OHL (24), magainin analog peptide Myp30 (20), bactericidal peptide of insect sarcotoxin IA (26) and sweet pepper ferredoxin-I protein (PFLP) $(17,21,33)$.

Ferredoxin-I (Fd-I) is an important member of photosynthesis proteins that transfer electrons from photosystem I (PSI) to the enzyme Fd:NADP ${ }^{+}$reductase for photoreduction of $\mathrm{NADP}^{+}$via the linear electron flow $(8,9,12)$. This reaction is involved in several fundamental metabolic processes (25). Recently, an Fd-I protein isolated from sweet pepper was identified that shares $84 \%$ identity in nucleotide sequence and $89.58 \%$ similarity in protein

Corresponding author: T.-Y. Feng; E-mail address: mpmi224@gate.sinica.edu.tw

doi:10.1094/PHYTO-97-8-0900

(c) 2007 The American Phytopathological Society sequence compared with Fd-I of tomato $(1,5)$. Over expression of Fd-I in transgenic plants led to intensified production of active oxygen species (AOS) and activation of the hypersensitive reaction (HR) when plants were challenged with bacterial pathogens or elicitors of defense responses $(5,17)$. These transgenic plants were resistant to foliar-infecting bacterial pathogens such as E. carotovora subsp. carotovora, P. syringae pv. tabaci, and $X$. oryzae pv. oryzae $(17,18,21,33)$.

Ralstonia solanacearum is a devastating bacterial pathogen of tomato worldwide. The bacterium infects root tissue and accumulates in stem tissue of hosts to cause serious wilting symptoms (10). To create a tomato variety resistant to $R$. solanacearum using PFLP, the protein will need to be expressed in root and stem tissues of transgenic tomato plants. However, PFLP is a member of Fd-I protein that only exist in the green tissue of plants (1). This tissue-specific expression of Fd-I might be due to two reasons. First, the original promoter of Fd-I is light inducible. Second, a certain specific sequence located in the 5'UTR is sensitive to degradation of protease that might cause instability of $f d-I$ gene mRNA under dark conductions (2). To circumvent these problems, the original promoter of the transgene was replaced with CaMV $35 \mathrm{~S}$ promoter and its 5'UTR was deleted. This modification might be beneficial for expression of PFLP in the root and stem tissue of transgenic tomato. In this study, we describe the selection of transgenic lines with highly expressed levels of PFLP. Challenge of these lines with $R$. solanacearum and E. carotovora subsp. carotovora resulted in a decrease in disease symptom production, indicating their potential for resistance to disease caused by these bacterial pathogens. 


\section{MATERIALS AND METHODS}

Generation and selection of transgenic tomato. Transformation of cherry tomato (Cln1558a) was performed using leaf discs with Agrobacterium tumefaciens C58C1 (16) containing the plasmid pBISPFLP. This plasmid was previously created by inserting the coding sequence of pflp gene into the vector pBI121 with the CaMV $35 \mathrm{~S}$ promoter (17). Successful transformations were selected with kanamycin $(50 \mu \mathrm{g} / \mathrm{ml})$ and verified by polymerase chain reaction (PCR) using the following primers (forward, 35S5': AAG GGA TGA CGC ACA ATC CCA CTA TCC TTC; reverse, PFLP-3' CGA GCT CGT TAG CCC ACG AGT TCT GCT TCT). These $T_{0}$ transgenic lines were self-pollinated to produce descendants and identified with PCR to define the $T_{1}$ transgenic lines. The same procedures were repeated to produce the $T_{2}$ transgenic lines from $T_{1}$. The $T_{2}$ transgenic tomato lines with $95 \%$ descendants containing foreign pflp gene were defined as homozygous lines.

Growth of bacterial pathogens and plants. The locally isolated $R$. solanacearum strains PS90 and PS95 were provided by Seed Improvement and Propagation Station (SIPS) and the virulently strain PSS190 (biovar 4 and aggressiveness group 1) was provided by Asian Vegetable Research and Development Center (19). All of these strains were cultured in 2,3,5-triphenyl tetrazolium chloride (TZC) medium consisting of $1 \%$ dextrose, $1 \%$ peptone, $0.1 \%$ casamino acids added with $0.1 \% \mathrm{TZC}$ at $28^{\circ} \mathrm{C}$ or $24 \mathrm{~h}$ with shaking at $175 \mathrm{rpm}$. E. carotovora subsp. carotovora strain Tw2 isolated in Taiwan was incubated in the nutrient broth medium (Difco, Le Pont de Claix, France) at $28^{\circ} \mathrm{C}$ for $24 \mathrm{~h}$ with shaking at $175 \mathrm{rpm}$.

All tomato plants were planted in the growth chamber with sterilized soil $\left(16 \mathrm{~h} \mathrm{light} / 8 \mathrm{~h}\right.$ dark at $\left.28^{\circ} \mathrm{C}\right)$ under the irradiance of $48 \mu \mathrm{mol} \mathrm{m} \mathrm{m}^{-2} \mathrm{~s}^{-1}$ for 1 month. The 1 -month-old tomato was then prepared for subsequent experiments.

Selection of resistant $T_{1}$ transgenic tomato lines. Equal volumes of two bacterial suspensions of $R$. solanacearum strain PS90 and PS95 $\left(1.0 \times 10^{7} \mathrm{CFU} / \mathrm{ml}\right)$ were mixed. The root tissue of 1-month-old $\mathrm{T}_{1}$ pflp-transgenic tomato plants were soaked in this bacterial mixture for $15 \mathrm{~min}$ and then transplanted into the ground of a simple greenhouse, which contained populations of strains PS90 and PS95 from previous experiments. Twenty plants of each line were used in this experiment. The degree of wilting was recorded in numerical grades as follows: no symptoms (0); one leaf partially wilted (1); 2 or 3 leaves wilting (2); 4 or 5 leaves wilting (3); all leaves wilting except the top (4) and the whole plant died (5). The disease index (DI) was calculated as DI = $\Sigma$ (grade $\times$ number of wilting plants $) /(5 \times$ number of total plants $)$.

$\mathbf{T}_{2}$ transgenic tomato inoculated with bacterial pathogens. The highly virulent $R$. solanacearum strain PSS190 that is able to infect more than six different cultivars tomato (19) was used to challenge $\mathrm{T}_{2}$ transgenic tomato. One liter of $R$. solanacearum strain PSS190 $\left(1 \times 10^{8} \mathrm{CFU} / \mathrm{ml}\right)$ was mixed with 16 liters of sterilized soil to produce disease soil. Thirty-six plants of each 1-month-old $\mathrm{T}_{2}$ transgenic line were transplanted in this disease soil. The degree of wilting symptom was recorded in numerical grades as description before.

Bacterial populations in stems of inoculated tomato plants were estimated by sectioning stems into four segments: the basal stem (BS), lower stem of the first branch (DS), upper stem of the first branch (US) and stem of the first branch (BB). One centimeter of the different stem sections of inoculated $\mathrm{T}_{2}$ transgenic tomato 2418-7 and nontransgenic tomato were ground with $100 \mu \mathrm{l}$ of sterilized water in a microfuge tube. Sample suspensions were serially diluted with sterilized water, plated on TZC agar plates, and incubated at $28^{\circ} \mathrm{C}$ for $24 \mathrm{~h}$ before counting to determine populations.

Soft-rot symptoms caused by E. carotovora subsp. carotovora were analyzed using detached leaves of $\mathrm{T}_{2}$ pflp-transgenic tomato. Detached leaves of 1-month-old plants were immersed in a $30-\mathrm{ml}$ suspension of $E$. carotovora subsp. carotovora $\left(5 \times 10^{4} \mathrm{CFU} / \mathrm{ml}\right)$. Leaves in the culture suspensions were incubated at room temperature with shaking at $75 \mathrm{rpm}$ under the irradiance of $48 \mu \mathrm{mol}$ $\mathrm{m}^{-2} \mathrm{~s}^{-1}$ for $40 \mathrm{~h}$. The total bacterial amount in the culture suspension of detached leaf was measured by absorption at $\mathrm{A}_{600}$ using U2000 Hitachi spectrophotometer.

Western blot analysis. Tomato tissue $(0.2 \mathrm{~g})$ was used to extract protein with $1 \mathrm{ml}$ of extracting buffer $(50 \mathrm{mM}$ Tris- $\mathrm{HCl}, \mathrm{pH}$ 8.0, $1 \%$ Triton X-100, $1 \mathrm{mM}$ EDTA, and PMSF). The concentration of the crude protein extract was measured with Coomassie Brilliant Blue dye (Bio-Rad). To confirm comparable quantities of transferred protein for each loading, PVDF membrane was stained with Ponceau S (Sigma-Aldrich, St. Louis) before immunolabeling. Crude extract ( $3 \mu \mathrm{g}$ ) was electrophoresed in 15\% SDS-PAGE and detected by western blot with polyclonal antiserum against PFLP. This antiserum was prepared from the previous study with recombinant PFLP in rabbit (18). It was able to recognize both PFLP and innate Fd-I of tomato in the crude extract.

Northern blot analysis. Total RNA was isolated from tomato leaves using the Qiagen Plant RNA Kit (Qiagen, GmBh). Total RNA $(15 \mu \mathrm{g})$ was electrophoresed in $1 \%$ agarose gel and then transferred onto nylon membranes. The membrane was hybridized overnight at $68^{\circ} \mathrm{C}$ with pflp-probe. The pflp-probe was prepared by PCR-labeling kit (Roche, Germany) with template (pBISPFLP) and primers (B5-SPF: 5'-CGG GAT CCC GAT GGC TAG TGT CTC AGC TAC CA-3', S3-PF: CGA GCT CGT TAG CCC ACG AGT TCT GCT TCT-3'). After hybridization, the membrane was washed under high stringency conditions and detected using the DIG Luminescent Detection Kit (Roche).

\section{RESULTS}

Screening of the $T_{1} p f l p$-transgenic disease resistant tomato lines. $\mathrm{T}_{1}$ pflp-transgenic tomatoes were inoculated with $R$. solanacearum strains PS90 and PS95 to select for resistant lines. The combined inoculation resulted in wilting symptoms in the nontransgenic tomato lines $C \ln 1558$ a with a disease index of 0.3 at 7 days postinoculation (dpi) that progressed to 0.5 at $18 \mathrm{dpi}$. In contrast, the commercial resistant tomato cultivar Mill TSS7 (TSS7) inoculated PS90 and PS95 resulted in a disease index of less than 0.05 at 13 dpi, reaching only 0.3 after 32 dpi. Similarly, the disease index of wilting symptoms caused by PS90 and PS95 in the transgenic line 14-7 was less than 0.05 at 7 days and 0.3 at 32 dpi. Lines 26-2, 24-3, 7-1 and 20-3 also showed reduced disease indices 0.1 at $7 \mathrm{dpi}$ and 0.3 at $32 \mathrm{dpi}$. However, while the disease index in line 23-1 was less than 0.1 at 7 dpi, it reached 0.5 at $32 \mathrm{dpi}$. In addition, the disease index in line 4-1 reached 0.3 at 7 dpi and 0.5 at 32 dpi (Fig. 1). These results showed that 5 individual $\mathrm{T}_{1}$ lines, 14-7, 26-2, 24-3, 7-1, and 20-3, showed some level of resistance to $R$. solanacearum as compared with the nontransgenic line.

Growth of $\mathbf{T}_{\mathbf{2}}$ pflp-transgenic tomato lines. To determine the effect of the foreign pflp gene on growth of transgenic tomato lines, seedling lengths of $36 \mathrm{~T}_{2}$ plants were monitored over the course of 1 month (Fig. 2). Seedling length of the nontransgenic line Cln1558a was $1.87 \mathrm{~cm}$ at 8 days and $4.78 \mathrm{~cm}$ at 22 days postplanting. The transgenic line 24-18-7 was greater than Cln1558a, with lengths of $2.74 \mathrm{~cm}$ after 8 days and $6.30 \mathrm{~cm}$ after 22 days. In contrast, line 26-2-1a was less than Cln1558a with lengths of 0.94 and $3.92 \mathrm{~cm}$ for 8 and 22 days, respectively. Transgenic line 2317-1b was similar to that of the control line (Fig. 2).

Expression profile of total Fd-I in transgenic tomato. The quantities of total $f d-I$ mRNA in leaf tissue of individual pflptransgenic lines were estimated by northern blot hybridizations using the pflp gene as a probe. The signal intensity of mRNA extracted from leaf tissue of nontransgenic tomato Cln1558a, transgenic lines 26-2-1a and 23-17-1b were weak (Fig. 3A). In contrast, the signal intensity of transgenic line $24-18-7$ was 28.06 -fold 
higher compared with the nontransgenic line. This result reveal that the total $f d-I$ mRNA was increased in the leaf tissue of transgenic line 24-18-7, but not in 26-2-1a and 23-17-1b.

The total Fd-I protein levels in different tissues of individual transgenic lines were estimated by western blot with polyclonal antiserum against PFLP. The intensity of hybridization was high in crude extract isolated from leaf and stem tissue, but low in root tissue of the nontransgenic tomato line $C \ln 1558 \mathrm{a}$. In contrast, the intensity of transgenic line 24-18-7 showed a 1.89-fold increase in leaf tissue, 1.57-fold increase in stem tissue and 12.12-fold increase in root tissue compared with nontransgenic line. The intensity of transgenic line 26-2-1a was increased 1.18-fold in leaf tissue and 13.37-fold in root tissue, but was reduced 0.74-fold in stem tissue compared with the control. In contrast, the intensity of transgenic line $23-17-1$ b was increased by 1.25 -fold in leaf tissue, but reduced 0.94 -fold in stem tissue and 0.98 -fold in root tissue (Fig. 3B). A point of emphasis is that the total content of Fd-I was significantly increased in the root tissue of transgenic line 24-18-7 and 26-2-1a.

$T_{2}$ pflp-transgenic tomato inoculated with $R$. solanacearum. To further study the effect of PFLP in disease resistance, the highly virulent $R$. solanacearum strain PSS190, which belongs to biovar 4 and aggressiveness group 1 (19), was used to challenge $\mathrm{T}_{2}$ transgenic tomato lines. This pathogen was able to cause a one-leaf partial wilting symptom at $1 \mathrm{dpi}$ (Fig. 4A), whole-plant wilting symptom at $7 \mathrm{dpi}$ (Fig. 4B) and death at $12 \mathrm{dpi}$ in the nontransgenic tomato line $\mathrm{Cln} 1558 \mathrm{a}$ (Fig. 4C). In contrast, the transgenic lines 24-18-7 and 26-2-1a remained healthy until 7 dpi. Slight wilting was observable at 9 dpi in transgenic lines 24-18-7 and 26-2-1a, but both lines remained alive at $12 \mathrm{dpi}$. In addition, the stems of transgenic lines were thicker in diameter compared to the diseased nontransgenic control at 12 dpi (Fig. 4D). Wilting symptoms caused by PSS190 in transgenic line 23-17-1b was similar to the nontransgenic line.

Disease indices of wilting symptoms were compared between inoculated tomato lines. Disease indices reached 0.33 at $1 \mathrm{dpi} ; 0.5$ at $7 \mathrm{dpi} ; 0.79$ at $9 \mathrm{dpi}$ and 0.9 at $12 \mathrm{dpi}$ for the nontransgenic tomato line. In contrast, disease indices remained below 0.1 until $7 \mathrm{dpi}$, followed by indices of 0.5 at $9 \mathrm{dpi}$ in both transgenic lines 24-18-7 and 26-2-1a. At $12 \mathrm{dpi}$, the disease index reached 0.75 for transgenic line 24-18-7, and 0.88 for transgenic line 26-2-1a. The disease index of inoculated transgenic line 23-17-1b was similar to the nontransgenic line (Fig. 4E). These results showed that transgenic lines 24-18-7 and 26-2-1a, but not 23-17-1b, were more resistant to PSS190 than the nontransgenic plants.

Populations of strain PSS190 were evaluated to determine the effect of overexpressed Fd-I in the stem tissue of inoculated tomato lines. The amount of PSS190 in all four different sections

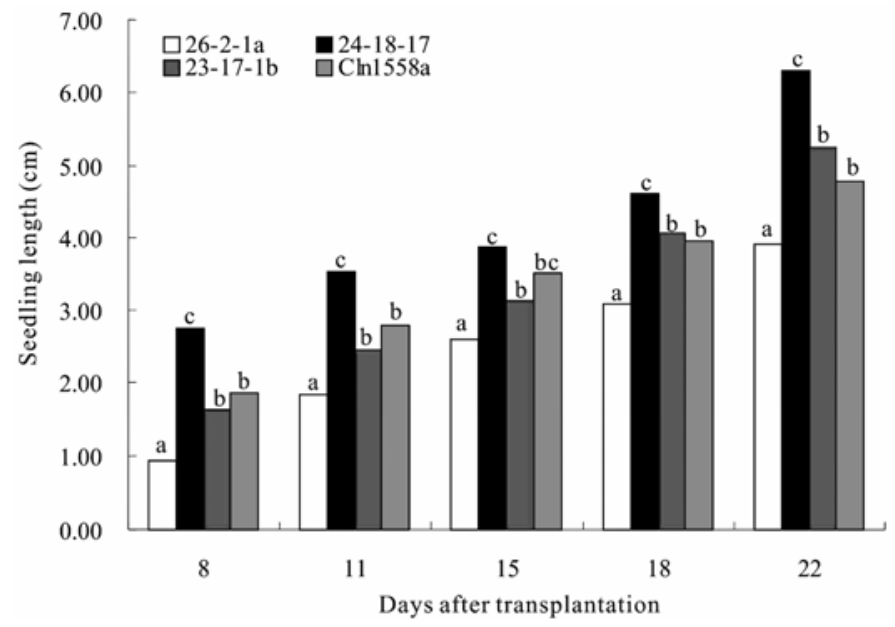

Fig. 2. Growth comparisons of $\mathrm{T}_{2}$ pflp-transgenic tomato lines. Plants of $\mathrm{T}_{2}$ pflp-transgenic lines 24-18-7, 26-2-1a and 23-17-1b and nontransgenic line Cln1558a were planted in the growth chamber and measured from the base of the crown to the top over a 22 day period. Values represent the means of thirty-six plants Different letters within each date indicate significant differences based on the Kruskal-Wallis test $(P<0.01)$.

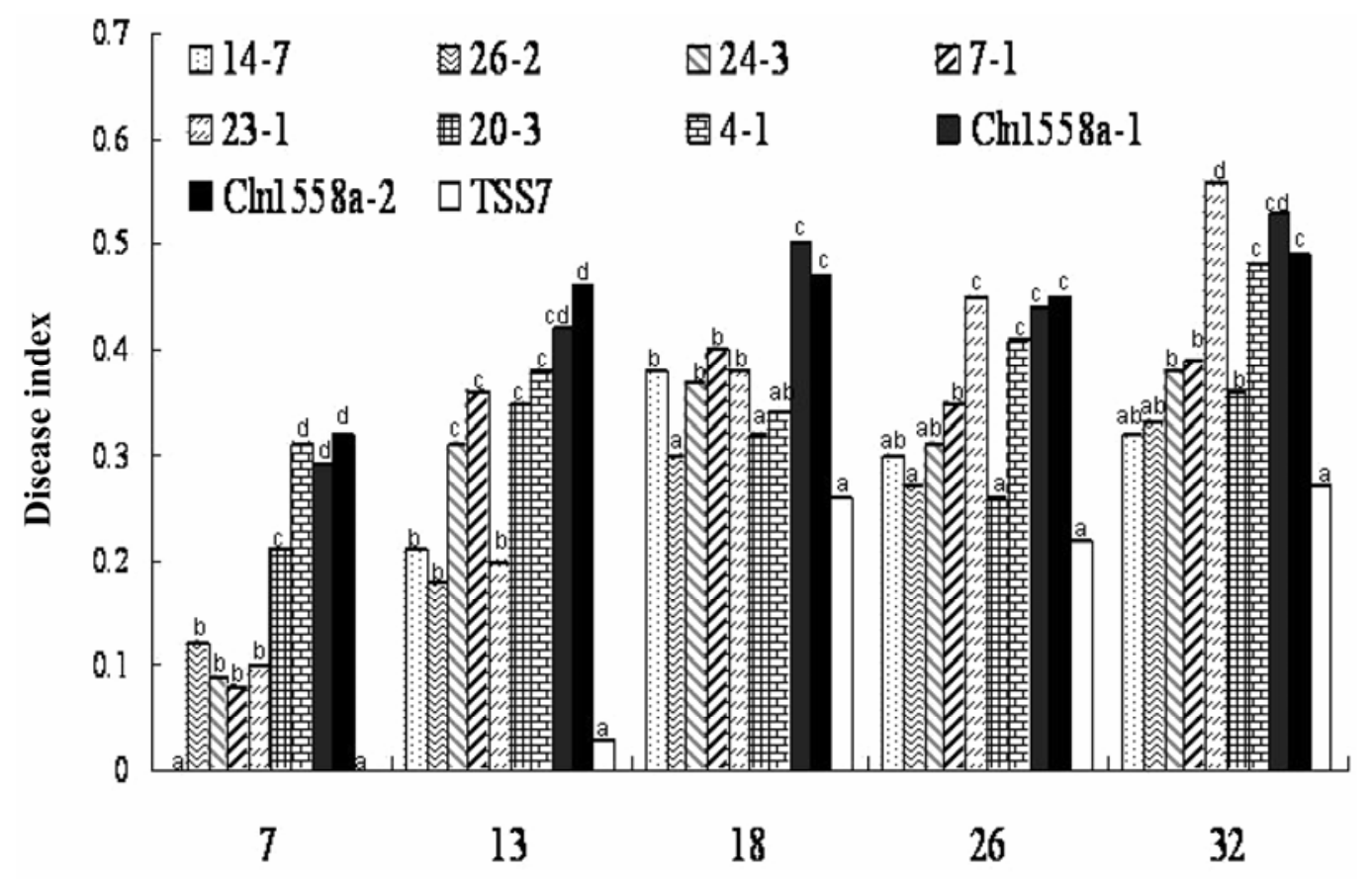

Days postinoculation

Fig. 1. Screening of $\mathrm{T}_{1}$ pflp-transgenic tomato lines for resistance to disease caused by Ralstonia solanacearum. One-month-old seedlings of $p f l p$-transgenic lines 4-1, 7-1, 14-7, 20-3, 23-1, 24-3 26-2, nontransgenic lines Cln1558a-1 and Cln1558a-2, and resistant line TSS7 were inoculated with a bacterial mixture of R. solanacearum strains PS90 and PS95 $\left(1.0 \times 10^{7} \mathrm{CFU} / \mathrm{ml}\right)$. Disease index represents the means of twenty plants of each line. Different letters within each date indicate significant differences based on the Kruskal-Wallis test $(P<0.01)$. 
of inoculated nontransgenic tomato reached $3.8 \times 10^{8} \mathrm{CFU} / \mathrm{cm}$ at 7 dpi. However, in transgenic line 24-18-7, populations were reduced to $4.1 \times 10^{7} \mathrm{CFU} / \mathrm{cm}$ in the BS section; $1 \times 10^{7} \mathrm{CFU} / \mathrm{cm}$ in the DS section; $3.5 \times 10^{6} \mathrm{CFU} / \mathrm{cm}$ in the US section and $5.3 \times$ $10^{5} \mathrm{CFU} / \mathrm{cm}$ in the BB section (Fig. 5). These results demonstrated that populations of PSS190 were much lower in stems of transgenic line 24-18-7 than in those of the nontransgenic line Cln1558a.

Detached leaves of transgenic tomato plants immersed in suspensions of Erwinia carotovora subsp. carotovora. A detached leaf assay was used to study the resistance of tomato to $E$. carotovora subsp. carotovora infection. Immersed leaves of nontransgenic tomato and transgenic line $23-17-1 \mathrm{~b}$ were significantly rotted $40 \mathrm{~h}$ after inoculation compared with transgenic lines 2418-7 and 26-2-1a (Fig. 6A). In addition, the total bacterial populations in the culture suspensions of detached leaves were measured by spectrophotometric absorption at $\mathrm{A}_{600}$. For nontransgenic tomato and transgenic line 23-17-1b, the absorption value of the suspension reached 0.05 at $24 \mathrm{hpi}$ and 0.3 at $40 \mathrm{hpi}$. In contrast, absorbance of the transgenic line $26-2-1 \mathrm{~b}$ was 0.03 at $24 \mathrm{hpi}$ and 0.14 at 40 hpi. Absorbance was limited to 0.02 at $24 \mathrm{hpi}$ and 0.05 at 40 hpi for the transgenic line 24-18-7 (Fig. 6B). This result showed that the detached leaf of transgenic line 24-18-7 reduced maceration by E. carotovora subsp. carotovora.

\section{DISCUSSION}

PFLP was able to increase tomato resistance to $R$. solanacearum (Fig. 1); however, some transgenic lines such as line 4-1 and line 23-1 displayed resistance to $R$. solanacearum only for an initial period of 13-18 days, compared to other lines with longer lasting resistance of 32 days. These variations might be due to the expression level of PFLP in respective transgenic lines. To further understand the effect of PFLP in transgenic tomato, a better understanding of PFLP expression levels in individual tissue of transgenic lines is necessary.

Expression levels of foreign genes in transgenic plants are usually dependent on promoter strength and mRNA translation. To increase the total amount of Fd-I, the pflp gene was overexpressed with the $35 \mathrm{~S}$ promoter in transgenic tomato lines. The protein expression levels of PFLP in root tissue of transgenic line 24-18-7 and 26-2-1a were high; however, expression levels in leaf tissue were low in the same lines (Fig. 3B). We suppose the high expression level in line 26-2-1a is due to the CaMV 35S promoter that is a common constitutive promoter, although expression levels of transgenes can differ substantially depending on plant species, organ, and plant developmental stage $(14,31)$. In the leaf tissue of transgenic line 24-18-7, mRNA expression levels of the pflp gene was high (Fig. 3A), but its protein expression level was low (Fig. 3B). It has been inferred that drastic changes in Fd-I/PSI ratios in green plant tissue can lead to cell death (15). Thus, it is reasonable that redundant $f d-I$ mRNA may prevent protein translation. In our experience, no live pflp-transgenic plants contain threefold higher Fd-I levels selected from the breeding process $(17,21$, 33). Thus, an unidentified posttranscription mechanism to prevent the translation of redundant Fd-I in plant leaf tissue might exist.

Quantitative changes of Fd-I in transgenic plants can have significant effects on metabolism $(9,25)$. Reducing the amount of Fd-I in transgenic plants result in limitation of photosynthesis efficiency and distribution of electrons (15). We supposed that overexpression of the sweet pepper Fd-I PFLP in transgenic plants might lead to a change in plant metabolism efficiency. Figure 2 shows that growth of $\mathrm{T}_{2}$ transgenic lines differed with varying expression of PFLP in individual tissue. The transgenic line 24-18-7, whose total Fd-I amount was increased in whole plant tissue, grew better than the nontransgenic line. In contrast, the transgenic line 26-2-1a, whose total Fd-I was only increased in root tissue, was dwarfed in growth. These morphological changes of transgenic tomato line might be the result from expression of PFLP in different tissue. However this phenomenon might also result from other effects such as gene disruption at the insertion site. To resolve this question, more investigations need to be done in the future.

Expression of PFLP in different plant tissues could enhance disease resistance to bacterial pathogens that infect these tissues. For example, transgenic lines 24-18-7 and 26-2-1a displayed higher expression levels of PFLP in root tissue, which coincided with lower disease caused by $R$. solanacearum, implying that disease resistance was due to expression of PFLP in root tissue. In addition, wilting symptoms caused by $R$. solanacearum in resistant line 26-2-1a occurred after $9 \mathrm{dpi}$, while 29-8-7 maintained its resistance. Line 26-2-1a expressed lower levels of PFLP in the stem tissue compared with 29-18-7. Thus, we hypothesized that the expression level of PFLP in the stem of transgenic tomatoes also contributes to resistance to bacterial wilt. To investigate this hypothesis, we compared the spread of $R$. solanacearum populations in different stem sections of transgenic line 24-18-7 with those of the nontransgenic line $C \ln 1558 \mathrm{a}$. Populations of $R$. solanacearum decreased in stem tissue of transgenic line 24-18-7 as the distance from the basic section increased (Fig. 5). This result correlates with accumulation of PFLP in the stem tissue of the transgenic tomato line (Fig. 3), implying that it is important for

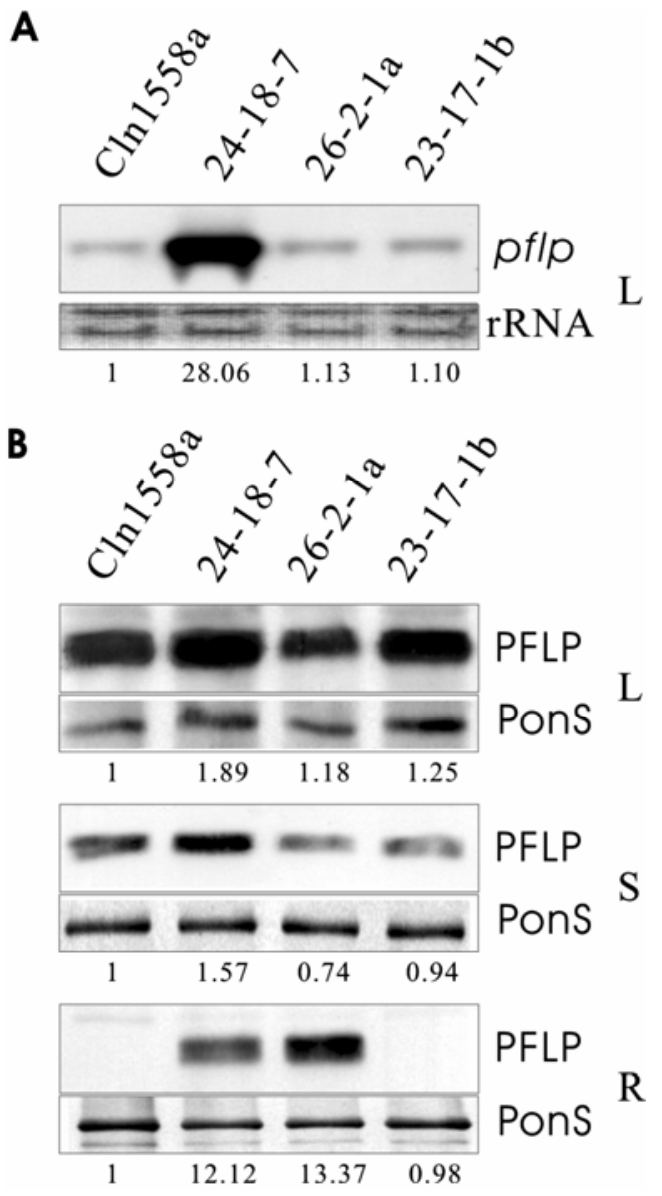

Fig. 3. Expression profiles of PFLP in tomato lines. A, Northern blot analysis using total RNA extracted from leaf tissue (L) of pflp-transgenic lines 24-187, 26-2-1a, and 23-17-1b, and nontransgenic line Cln1558a hybridized with the pflp gene. Relative signal intensities are indicated under each lane as compared with Cln1558a. B, Western blot analyses of crude protein extracts isolated from leaf $(\mathrm{L})$, stem $(\mathrm{S})$, and root $(\mathrm{R})$ tissues of transgenic lines 24-187, 26-2-1a, and 23-17-1b, and nontransgenic line Cln1558a hybridized with antiserum against PFLP. Loading amount of crude extract was normalized by staining with Ponceau $\mathrm{S}$ (PonS) before immunolabeling. The relative protein amounts comparison with $\mathrm{Cln} 1558$ a were calculated with digital intensity and noted underneath. 
enhancing disease resistance to $R$. solanacearum. Detached leaves of transgenic line 24-18-7 had higher levels of Fd-I compared with the nontransgenic line (Fig. 3), and displayed resistance to maceration caused by E. carotovora subsp. carotovora (Fig. 6). In contrast, resistance to maceration was not apparent in detached leaves of transgenic lines 26-2-1a and 23-17-1b, which displayed similar levels of total Fd-I as compared with the nontransgenic line. This result is consistent in our previous studies that demon-
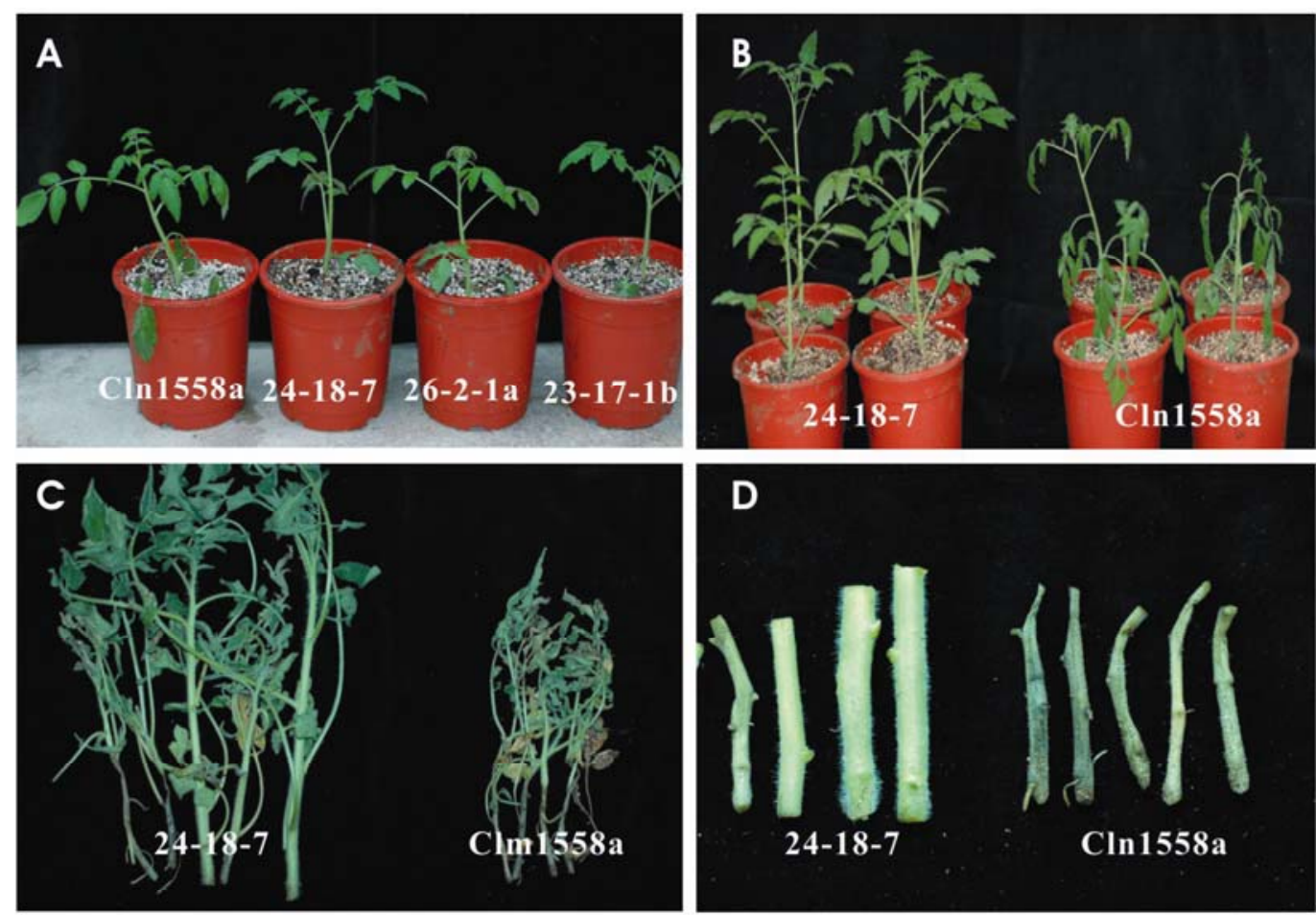

$\mathbf{E}$

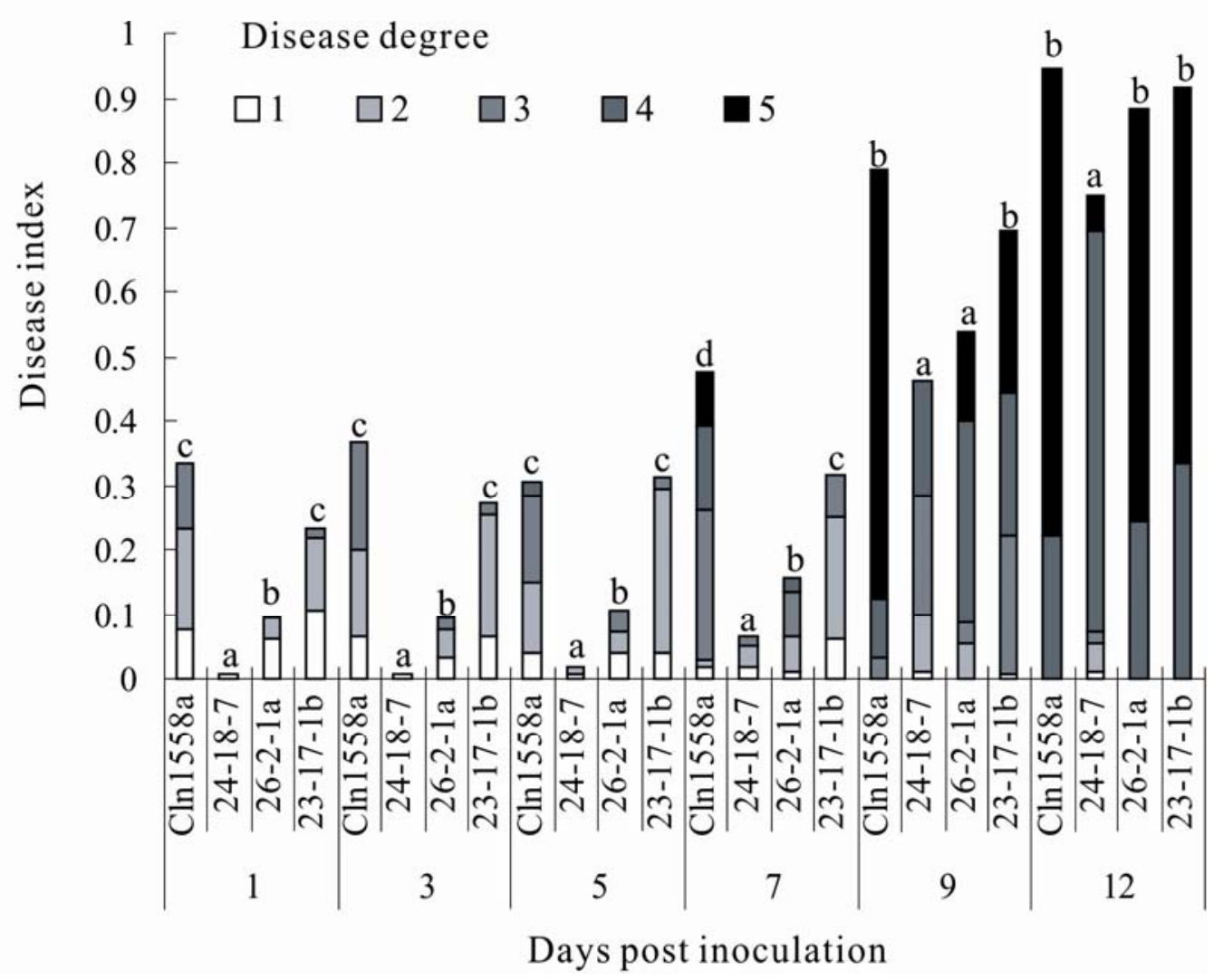

Fig. 4. Disease progression in $\mathrm{T}_{2}$ pflp-transgenic tomato inoculated with Ralstonia solanacearum. One-month-old plants of transgenic lines 24-18-7, 26-2-1a, and 23-17-1b, and nontransgenic line Cln1558a were inoculated with $R$. solanacearum PSS190. Representative plants at A, 1 day, B, 7 days, and C, 12 days after inoculation. D, Cut stem sections of inoculated plants at 12 days postinoculation. E, Disease index values for each plant line over a 12 day period. Different letters within each date indicate significant differences based on the Kruskal-Wallis test $(P<0.01)$. 


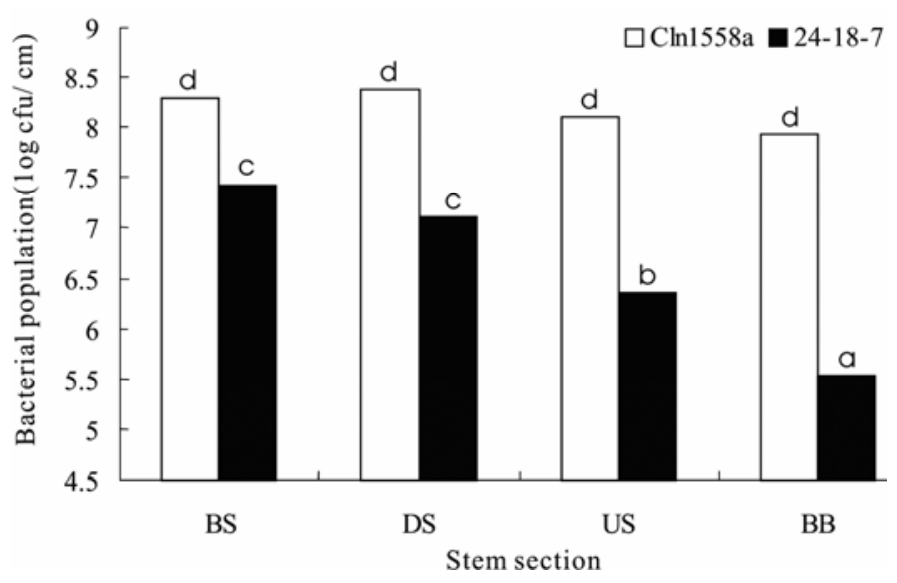

Fig. 5. Expansion of Ralstonia solanacearum populations in different stem sections of inoculated tomato plants. One-month-old plants of transgenic tomato line 24-18-7 and nontransgenic tomato line Cln1558a were inoculated with PSS190. After 7 days, $R$. solanacearum populations were determined in 1-cm stem sections classified into four groups: the basal stem (BS), lower stem of the first branch (DS), upper stem of the first branch (US) and stem of the first branch (BB). Within each section, the different letters indicate significant differences based on the Kruskal-Wallis test $(P<0.01)$. strated expression of PFLP in leaf tissue of transgenic plant lines enhances resistance to bacterial diseases caused by leaf-infecting pathogens $(17,21,33)$.

In this study, we created transgenic tomato lines that overexpress the Fd-I protein, which generally exists in all green tissue of plants. This protein in the transgenic line 24-18-7 was able to increase plant growth and resistance to disease caused by $R$. solanacearum and E. carotovora subsp. carotovora. Since $R$. solanacearum and E. carotovora subsp. carotovora are devastating bacterial pathogens of crops worldwide, these results imply that crop quality could be improved by artificially regulating total Fd-I amounts in plants.

\section{ACKNOWLEDGMENTS}

We thank the Asian Vegetable Research and Development Center (AVRDC) for providing the pathogen $R$. solanacearum strain pss 190 and tomato line Lycopersicum esculentum cv. cherry Cln1558a; and the Seed Improvement and Propagation Station (SIPS) for providing the resistant tomato line. This work was supported by the grants to T.-Y. Feng from Academia Sinica, Taiwan, Republic of China and to C.-A. Lu from AVRDC

\section{LITERATURE CITED}

1. Aoki, K., and Wada, K. 1996. Temporal and spatial distribution of ferredoxin isoproteins in tomato fruit. Plant Physiol. 112:651-657.

2. Bhat, S., Tang, L., Krueger, A. D., Smith, C. L., Ford, S. R., Dickey, L. F.
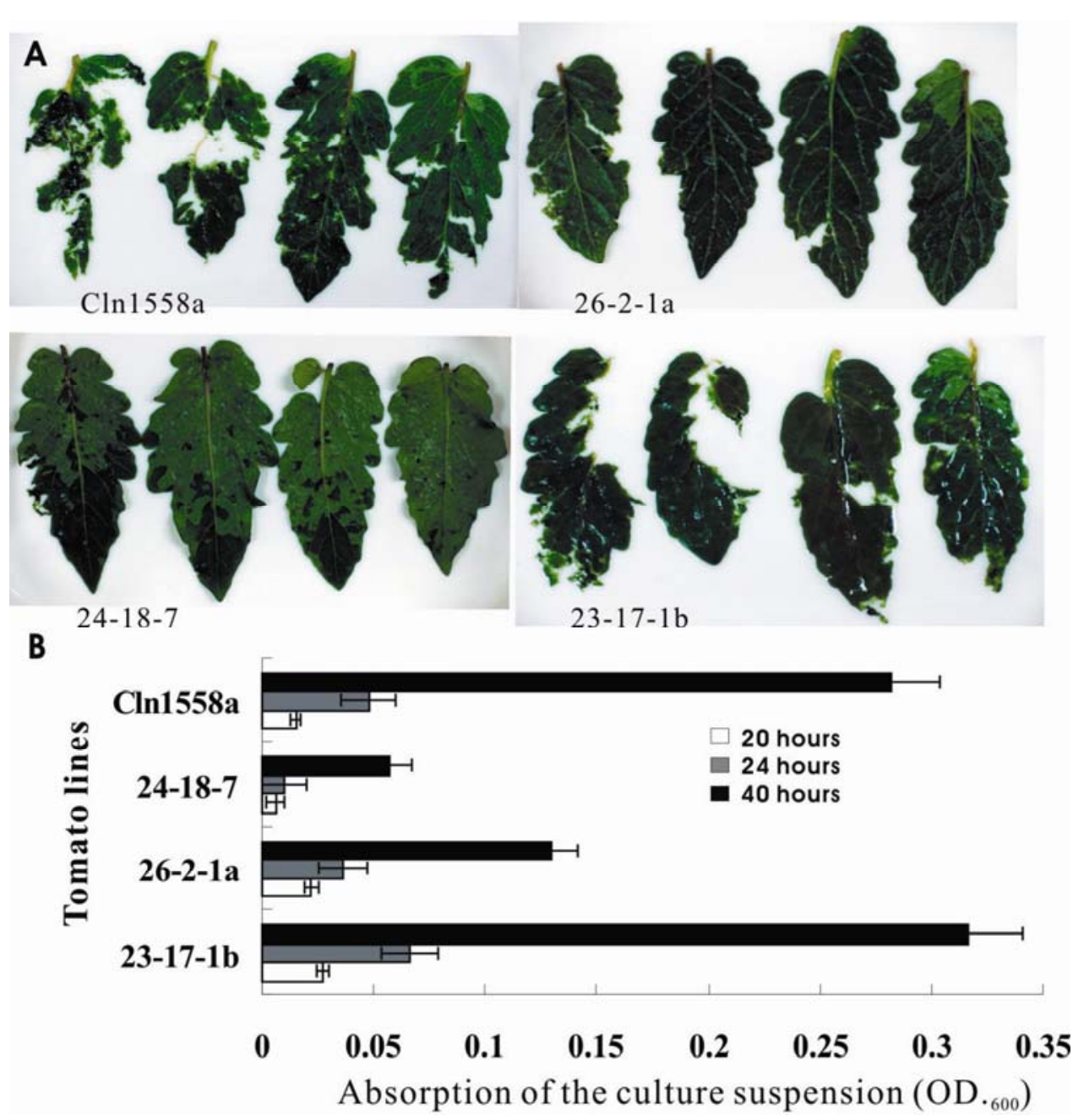

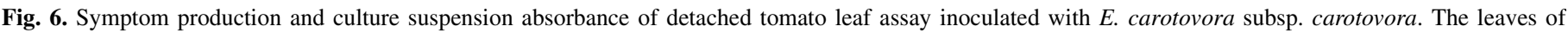

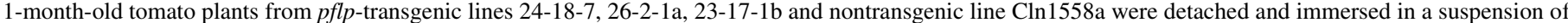

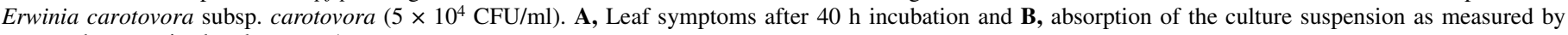
spectrophotometric absorbance at $\mathrm{A}_{600}$. 
and Petracek, M. E. 2004. The Fed-1 (CAUU) ${ }_{4}$ element is a 5' UTR darkresponsive mRNA instability element that functions independently of dark-induced polyribosome dissociation. Plant Mol Biol. 56:761-773.

3. Chan, Y. L., Prasad, V., Sanjaya, Chen, K. H., Liu, P. C., Chan, M. T., and Cheng, C. P. 2005. Transgenic tomato plants expressing an Arabidopsis thionin (Thi2.1) driven by fruit-inactive promoter battle against phytopathogenic attack. Planta 221:386-393.

4. Chern, M., Fitzgerald, H. A., Canlas, P. E., Navarre, D. A., and Ronald, P. C. 2005. Overexpression of a rice NPR1 homolog leads to constitutive activation of defense response and hypersensitivity to light. Mol. PlantMicrobe Interact. 18:511-520.

5. Dayakar, B. V., Lin, H. J., Chen, C. H., Ger, M. J., Lee, B. H, Pai, C. H., Chow, D., Huang, H. E., Hwang, S. Y., Chung, M. C., and Feng, T. Y. 2003. Ferredoxin from sweet pepper (Capsicum апnиит L.) intensifying harpin $_{(\mathrm{pss})}$-mediated hypersensitive response shows an enhanced production of active oxygen species (AOS). Plant Mol. Biol. 51:913-924.

6. Elfstrand, M., Sitbon, F., Lapierre, C., Bottin, A., and von Arnold, S. 2002. Altered lignin structure and resistance to pathogens in spi 2expressing tobacco plants. Planta. 214:708-716.

7. Fitzgerald, H. A., Chern, M. S., Navarre, R., and Ronald, P. C. 2004. Overexpression of (At)NPR1 in rice leads to a BTH- and environmentinduced lesion-mimic/cell death phenotype. Mol. Plant-Microbe Interact. 17:140-151.

8. Gallo-Meagher, M., Sowinski, D. A., Elliott, R. C., and Thompson, W. F. 1992. Both endogenous and external regulatory elements control expression of the pea Fed-1 gene in transgenic tobacco seedlings. Plant Cell 4:389-395.

9. Geigenberger, P., Kolbe, A., and Tiessen, A. 2005. Redox regulation of carbon storage and partitioning in response to light and sugars. J. Exp. Bot. 56:1469-1479.

10. Genin, S., and Boucher, C. 2004 Lessons learned from the genome analysis of ralstonia solanacearum. Annu. Rev. Phytopathol. 42:107-134.

11. Ger, M. J., Chen, C. H., Hwang, S. Y., Huang, H. E., Podile, A. R., Dayakar, B. V., and Feng, T. Y. 2002. Constitutive expression of hrap gene in transgenic tobacco plant enhances resistance against virulent bacterial pathogens by induction of a hypersensitive response. Mol. Plant-Microbe Interact. 15:764-773.

12. Green, L. S., Yee, B. C., Buchanan, B. B., Kamide, K., Sanada, Y., and Wada, K. 1991. Ferredoxin and ferredoxin-NADP reductase from photosynthetic and nonphotosynthetic tissues of tomato. Plant Physiol. 96:1207-1213.

13. Gurr, S. J., and Rushton, P. J. 2005. Engineering plants with increased disease resistance: what are we going to express? Trends Biotechnol. 23:275-282.

14. Gurr, S. J., and Rushton, P. J. 2005. Engineering plants with increased disease resistance: how are we going to express it? Trends Biotechnol. 23:283-290.

15. Holtgrefe, S., Bader, K. P., Horton, P., Scheibe, R., von Schaewen, A., and Backhausen, J. E. 2003. Decreased content of leaf ferredoxin changes electron distribution and limits photosynthesis in transgenic potato plants. Plant Physiol. 133:1768-1778.

16. Horsch, R. B., Fry, J. E., Hofmannn, N. L., Eichholtz, D., Rogers, S. G.. and Fraley, R. T. 1985. A simple and general method for transferring genes into plants. Science 227: 1229-1231.

17. Huang, H. E., Ger, M. J., Yip, M. K., Chen, C. Y., Pandey, A. K., and Feng, T. Y. 2004. A hypersensitive response was induced by virulent bacteria in transgenic tobacco plants overexpressing a plant ferredoxinlike protein (PFLP). Physiol. and Mol. Plant Pathol. 64:103-110.

18. Huang, H.E. Ger, M. J., Chen, C. Y., Yip, M. K. Chung, M. C. and Feng, T. Y. 2006. Plant ferredoxin-like protein (PFLP) exhibits an anti-microbial ability against soft-rot pathogen Erwinia carotovora subsp. carotovora in vitro and in vivo. Plant Sci. 171:17-23.

19. Jaunet, T. X., and Wang, J. F. 1999. Variation in genotype and aggressiveness of Ralstonia solanacearum race 1 isolated from tomato in Taiwan. Phytopathology 89:320-327.

20. Li, Q., Lawrence, C. B., Xing, H. Y., Babbitt, R. A., Bass, W. T., Maiti, I. B., and Everett, N. P. 2001. Enhanced disease resistance conferred by expression of an antimicrobial magainin analog in transgenic tobacco. Planta. 212:635-639.

21. Liau, C. H., Lu, J. C., Prasad, V., Hsiao, H. H., You, S. J., Lee, J. T., Yang, N. S., Huang, H. E., Feng, T. Y., Chen, W. H., and Chan, M. T. 2003. The sweet pepper ferredoxin-like protein ( $p f l p$ ) conferred resistance against soft rot disease in Oncidium orchid. Transgenic Res. 12:329-336.

22. Lin, W. C., Lu, C. F., Wu, J. W., Cheng, M. L., Lin, Y. M., Yang, N. S., Black, L., Green, S. K., Wang, J. F., and Cheng, C. P. 2004. Transgenic tomato plants expressing the Arabidopsis NPR 1 gene display enhanced resistance to a spectrum of fungal and bacterial diseases. Transgenic Res. 13:567-581.

23. Lorenc-Kukula, K., Jafra, S., Oszmianski, J., and Szopa, J. 2005. Ectopic expression of anthocyanin 5-o-glucosyltransferase in potato tuber causes increased resistance to bacteria. J Agric Food Chem. 53:272-281.

24. Mae, A., Montesano, M., Koiv, V., and Palva, E. T. 2001. Transgenic plants producing the bacterial pheromone $\mathrm{N}$-acyl-homoserine lactone exhibit enhanced resistance to the bacterial phytopathogen Erwinia carotovora. Mol. Plant-Microbe Interact. 14:1035-1042.

25. Meyer, J. 2001. Ferredoxins of the third kind. FEBS Lett. 509:1-5.

26. Ohshima, M., Mitsuhara, I., Okamoto, M., Sawano, S., Nishiyama, K., Kaku, H., Natori, S., and Ohashi, Y. 1999. Enhanced resistance to bacterial diseases of transgenic tobacco plants overexpressing sarcotoxin IA, a bactericidal peptide of insect. J Biochem, (Tokyo) 125:431-435.

27. Osusky, M., Osuska, L., Hancock, R. E., Kay, W. W., and Misra, S. 2004. Transgenic potatoes expressing a novel cationic peptide are resistant to late blight and pink rot. Transgenic Res. 13:181-190.

28. Pandey, A. K., Ger, M. J., Huang, H. E., Yip, M. K., Zeng, J., and Feng, T. Y. 2005. Expression of the hypersensitive response-assisting protein in Arabidopsis results in harpin-dependent hypersensitive cell death in response to Erwinia carotovora. Plant Mol. Biol. 59:771-780.

29. Rommens, C. M., and Kishore, G. M. 2000. Exploiting the full potential of disease-resistance genes for agricultural use. Curr. Opin. Biotechnol 11:120-125.

30. Salmeron, J. M., and Vernooij, B. 1998. Trnasgenic approaches to microbial disease resistance in crop plants. Curr. Opin. Plant Biol. 1:347352.

31. Samac, D. A., Tesfaye, M., Dornbusch, M., Saruul, P., and Temple, S. J. 2004. A comparison of constitutive promoters for expression of transgenes in alfalfa (Medicago sativa). Transgenic Res. 13:349-361.

32. Stuiver, M. H., and Custers, J. H. 2001. Engineering disease resistance in plants. Nature 411:865-868.

33. Tang, K., Sun, X., Hu, Q., Wu, A., Lin, C., Lin, H., Twyman, R. M., Christou, P., and Feng, T. Y. 2001. Transgenic rice plants expressing the ferredoxin-like protein (AP1) from sweet pepper show enhanced resistance to Xanthomonas oryzae pv. oryzae. Plant Sci. 160:1035-1042.

34. Yi, J. Y., Seo, H. W., Yang, M. S., Robb, E. J., Nazar, R. N., and Lee, S. W. 2004. Plant defense gene promoter enhances the reliability of shiva-1 gene-induced resistance to soft rot disease in potato. Planta 220:165-171.

35. Zhang, H., Zhang, D., Chen, J., Yang, Y., Huang, Z., Huang, D., Wang, X. C., and Huang, R. 2004. Tomato stress-responsive factor TSRF1 interacts with ethylene responsive element GCC box and regulates pathogen resistance to Ralstonia solanacearum. Plant Mol. Biol. 55:825-834. 